\title{
Large Chestnut Trees (Castanea sativa) Respond Poorly to Liming and Fertilizer Application
}

\author{
M. Ângelo Rodrigues ${ }^{1}$ (D) $\cdot$ Soraia Raimundo ${ }^{1} \cdot$ Abel Pereira $^{2} \cdot$ Margarida Arrobas $^{1}$ (i)
}

Received: 12 November 2019 / Accepted: 25 February 2020

(C) Sociedad Chilena de la Ciencia del Suelo 2020

\begin{abstract}
Establishing a fertilization plan for large trees is particularly difficult due to the high soil volume that the roots exploit and the buffer effect of the perennial woody structure on the concentration of nutrients in the leaves. This work evaluates the response of chestnut, a very large tree, to different fertilizer solutions. The study was conducted in two chestnut orchards planted in acid soils that were subjected to the application of lime plus phosphorus (Lime+P), lime plus a compound NPK fertilizer (Lime+NPK), and an unfertilized control (Control). The effects of the treatments on soil properties, nutritional status and photosynthetic performance of the trees, and nut production, were assessed from field and laboratory analyses. Liming significantly increased soil $\mathrm{pH}$ and exchangeable calcium (Ca). Treatments did not significantly influence leaf $\mathrm{P}$ and $\mathrm{K}$ levels, although leaf $\mathrm{N}$ concentrations were significantly higher in the Lime+NPK treatment on two of the three sampling dates. In one of the trials, the average accumulated nut yield was higher in the Lime+NPK $\left(71.7 \mathrm{~kg}^{-1} \mathrm{e}^{-1}\right)$ treatment compared with the control $\left(59.6 \mathrm{~kg}\right.$ tree $\left.{ }^{-1}\right)$ and the Lime+P $\left(51.7 \mathrm{~kg}\right.$ tree $\left.{ }^{-1}\right)$ treatments, although without significant differences at $P<0.05$. Overall, the results show the chestnut tree to be a species tolerant of soil acidity. The results also show that the buffer capacity of the plant in regulating the nutrient concentration in the leaves seems to be higher for $\mathrm{P}$ than for $\mathrm{N}$, and therefore, concentrations of $\mathrm{N}$ in the leaves require the regular application of the nutrient as a fertilizer.
\end{abstract}

Keywords Soil acidity $\cdot$ Plant nutritional status $\cdot$ NDVI $\cdot$ SPAD readings $\cdot$ Chlorophyll fluorescence $\cdot$ Nut yield

\section{Introduction}

Sweet chestnut (Castanea sativa Mill.) is a tree species with a long history in the Iberian Peninsula, one of the places in which it found refuge in the last glacial period (Krebs et al. 2019). It has been widely cultivated in this region since the Roman colonization of Hispania, having assumed in several periods a crucial role in the survival of the populations in the mountainous regions, especially before the arrival of the potato (Solanum tuberosum L.) (Abreu 2007).

It has long been an important agroforestry species, used for timber, firewood, and nut production for both human and

M. Ângelo Rodrigues

angelor@ipb.pt

1 Centro de Investigação de Montanha (CIMO), Instituto Politécnico de Bragança, Campus de Sta Apolónia, 5300-253 Bragança, Portugal

2 ARBOREA - Associação Agro-Florestal e Ambiental da Terra Fria Transmontana, Rua Dr. Álvaro Leite, no. 3,

5320-332 Vinhais, Portugal animal consumption (pigs in particular). Although in recent years the consumption of firewood and the price of chestnut wood have decreased, interest in the chestnut for fruit production has increased not only in Europe but also in Asia, the USA, South America (Brazil and Chile), Australia, and New Zealand (Pereira et al. 2011). The high dietary value of the fruits (Borges et al. 2008; Rusu et al. 2019), together with a range of diseases and pests, notably chestnut ink [Phytophthora cinnamoni Rand and P. cambivora (Petri) Buisman] (Gouveia et al. 2005; Maurel et al. 2001), chestnut blight [Cryphonectria parasitica (Murrill) Barr.] (Murolo et al. 2019), and the invasive gall wasp (Dryocosmus kuriphilus Yasumatsu) originating in Asia (Gençer and Mert 2019), have all raised the price of the nuts, thereby increasing producers' interest in the crop.

Chestnut is frequently grown in mountainous regions, sometimes at high altitudes where crop chilling requirements are assured as well as plenty of rainfall. In Portugal, in the most important chestnut growing regions, average air temperature is between 9 and $13{ }^{\circ} \mathrm{C}$ and precipitation between 800 and $900 \mathrm{~mm}$, although it could be successfully grown outside 
of these parameters (Gomes-Laranjo et al. 2007). In these mountainous regions, where chestnut is an important crop, acidic soils predominate (Arrobas et al. 2018; Nunes et al. 2011; Portela et al. 2011). At low pH values, and on soils high in aluminum $(\mathrm{Al})$ and iron $(\mathrm{Fe}), \mathrm{P}$ precipitates as insoluble $\mathrm{Fe} /$ Al-P compounds (Havlin et al. 2014; Park and Ro 2018), conditions that can be favorable for P fertilizers and lime to acquire a relevant role in chestnut fertilization.

Chestnut trees for fruit production were traditionally planted as isolated trees in the most fertile parts of the cereal fields or in small orchards of widely spaced trees on the concave parts of the terrain. Until a few years ago, chestnut trees were usually not fertilized. However, they often received the side effects of fertilization applied to cereals grown under their canopies, or in rare cases, as direct applications, where manure was available on farms. In recent years, with a view to increasing productivity and the size of the nuts, growers have begun to fertilize their orchards. Taking into account the agroecological conditions where chestnut is usually grown, and in particular, soil acidity, lime, and P fertilizers have been the most widely recommended applications (Arrobas et al. 2016).

This strategy, however, has been developed by only considering the environment in which the chestnut tree is grown, with no reference to fertilizer response trials, which would give vital feedback on the effectiveness of such a strategy. Plants that have evolved in such environments tend to be tolerant of soil acidity and may overcome the poor soil P levels by establishing symbiotic relationships with ectomycorrhizal fungi (Pereira et al. 2012). Furthermore, the reliability of a diagnosis based on soil analysis in orchards is low due to the high amount of soil that the roots exploit (Righetti et al. 1990; Rodrigues et al. 2012). A mature chestnut tree can be huge, which reduces the quality of a diagnosis based only on soil analysis. Diagnoses made from leaf analysis are also unsafe, since the large perennial structure of the plant, in particular the root system, may buffer the nutrient concentrations in the leaves. Chestnut may fulfill half of its requirements of $\mathrm{N}, \mathrm{P}$, and $\mathrm{K}$ from internal translocation of the nutrients and through recycling of debris (leaves, burs) in the upper part of the soil (ColinBelgrand et al. 1996). The sufficiency ranges themselves have previously been chosen as the range where most of the results of leaf analysis fall, and have not been based necessarily on fertilizer response studies, since these have not been sufficiently numerous (Arrobas et al. 2018).

Given the enormous importance that sweet chestnut has been gaining in the mountainous regions where it is currently cultivated, and with the planting of trees in orchards at higher densities and occupying increasingly less fertile soils, the pressure to apply fertilizer is becoming more urgent to ensure higher yields and profits
(Rodrigues et al. 2019). Thus, the objective of this work is to assess the response of the chestnut tree, a plant of enormous size, to the application of lime and P-rich fertilizers, currently the most common fertilization strategies in the region, in two field trials established in mature orchards. We are interested to test if chestnut can indeed respond to liming and fertilizer application, despite the size of the trees and their ability to buffer the nutrient concentration in the leaves, taking into account that in previous studies in the region perennial crops have shown a poor response to lime and $\mathrm{P}$ fertilizers (Arrobas et al. 2017; Ferreira et al. 2018a).

\section{Materials and Methods}

\subsection{Experimental Conditions}

The field trials took place in the municipality of Vinhais, NE Portugal, in Sobreiró (41.833485, - 7.053362) and Salgueiros (41.893505, - 7.055719). The region's climate is of Mediterranean type, "Csb" according to the Köppen climate classification. Average monthly precipitation and temperature recorded at Qta de Sta Apolónia weather station, located 35 and $40 \mathrm{~km}$ away, respectively, from Sobreiró and Salgueiros are shown in Fig. 1. Total annual precipitation and average temperature are $772.8 \mathrm{~mm}$ and $12.7^{\circ} \mathrm{C}$, respectively. In 2015 , 2016, and 2017, these values were respectively $419.4,786.1$, and $505.7 \mathrm{~mm}$ and $12.8,12.9$, and $13.7^{\circ} \mathrm{C}$.

The Sobreiró assay was installed on a dystric Cambisol (WRB 2015) clay loamy textured (39\% clay, 31\% silt, 30\% sand). The Salgueiros soil is a humic Cambisol (WRB 2015), also clay loamy textured ( $30 \%$ clay, $25 \%$ silt, and $45 \%$ sand). Both soils are acidic, although the Salgueiros soil has a lower $\mathrm{pH}$. The organic matter content is higher in Salgueiros than in Sobreiró. Several soil properties determined at the beginning of the field trial installation from samples taken at 0-10-, 10 $20-$, and 20-30-cm depth are shown in Table 1.

\subsection{Experimental Design and Characterization of Fertilizing Materials}

The trials were arranged as block designs with three fertilizer treatments and five replications. In a chestnut grove, the trees are very heterogeneous in size, due to abnormally high tree growth and phytosanitary problems, such as ink and blight diseases. The orchards are therefore composed of trees of very different size and age due to death and replanting. Thus, the experiments were organized in randomized blocks. Five groups of three very homogeneous trees within the group were formed. The three fertilizer treatments were randomly applied to each tree within a group to remove the experimental variability. The fertilizer treatments were defined taking into 
Fig. 1 Average monthly temperature and precipitation recorded in the meteorological station of Sta Apolónia farm during the experimental period

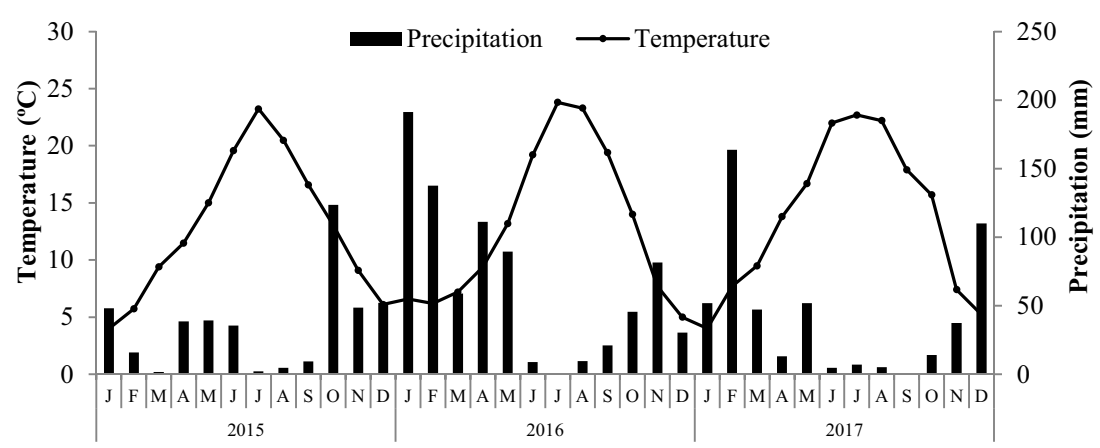

2.3 Management of Field Trials and Soil and Tissue Sampling

The orchard floor of Sobreiró is managed by conventional tillage, by passing the cultivator twice a year. In Salgueiros, the ground is maintained with a cover of natural vegetation which is mowed annually in spring. Thus, the fertilizers in Sobreiró were incorporated into the soil shortly after application and in Salgueiros they were left on the ground with no incorporation. In both trials, the fertilizers were manually applied, homogeneously spread beneath the canopy.

The initial soil samples were randomly taken from beneath the canopies throughout the orchard at three different depths (0-10, 10-20, and 20-30 cm). Three composite samples per depth were prepared, each consisting of fifteen individual collections. The final soil sampling for the evaluation of the effect of the treatments was also performed at the three depths abovementioned, but each composite sample consisted of five replications taken under the canopy of each tree.
Table 1 Selected soil properties determined from soil samples taken just before the installation of the experiments

\begin{tabular}{|c|c|c|c|c|c|c|}
\hline \multirow[b]{2}{*}{ Soil layer $(\mathrm{cm})$} & \multicolumn{3}{|l|}{ Sobreiró } & \multicolumn{3}{|l|}{ Salgueiros } \\
\hline & $0-10$ & $10-20$ & $20-30$ & $0-10$ & $10-20$ & $20-30$ \\
\hline${ }^{1}$ Organic $\mathrm{C}\left(\mathrm{g} \mathrm{kg}^{-1}\right)$ & $12.3 \pm 0.63$ & $9.7 \pm 1.16$ & $7.1 \pm 0.71$ & $26.0 \pm 0.33$ & $17.5 \pm 0.54$ & $14.6 \pm 1.67$ \\
\hline${ }^{2} \mathrm{pH}\left(\mathrm{H}_{2} \mathrm{O}\right)$ & $5.8 \pm 0.25$ & $5.6 \pm 0.18$ & $5.3 \pm 0.07$ & $5.1 \pm 0.23$ & $4.9 \pm 0.11$ & $4.9 \pm 0.14$ \\
\hline${ }^{2} \mathrm{pH}(\mathrm{KCl})$ & $4.6 \pm 0.24$ & $4.3 \pm 0.12$ & $3.9 \pm 0.05$ & $4.1 \pm 0.19$ & $4.0 \pm 0.07$ & $4.0 \pm 0.07$ \\
\hline \multicolumn{7}{|l|}{ Extractable } \\
\hline${ }^{3} \mathrm{P}\left(\mathrm{mg} \mathrm{P}_{2} \mathrm{O}_{5} \mathrm{~kg}^{-1}\right)$ & $66 \pm 38.0$ & $14 \pm 3.8$ & $5 \pm 3.2$ & $44 \pm 21.9$ & $33 \pm 22.9$ & $23 \pm 17.9$ \\
\hline${ }^{3} \mathrm{~K}\left(\mathrm{mg} \mathrm{K}_{2} \mathrm{O} \mathrm{kg}{ }^{-1}\right)$ & $217 \pm 48.3$ & $171 \pm 7.8$ & $145 \pm 17.9$ & $192 \pm 46.9$ & $152 \pm 18.7$ & $134 \pm 26.3$ \\
\hline${ }^{4} \mathrm{~B}\left(\mathrm{mg} \mathrm{kg}^{-1}\right)$ & $0.6 \pm 0.17$ & $0.4 \pm 0.09$ & $0.4 \pm 0.15$ & $0.6 \pm 0.06$ & $0.5 \pm 0.21$ & $0.6 \pm 0.38$ \\
\hline \multicolumn{7}{|c|}{${ }^{5}$ Exchangeable complex } \\
\hline $\mathrm{Ca}\left(\mathrm{cmol}_{\mathrm{c}} \mathrm{kg}^{-1}\right)$ & $5.1 \pm 0.15$ & $4.4 \pm 0.36$ & $4.0 \pm 0.63$ & $2.4 \pm 1.12$ & $1.6 \pm 0.45$ & $1.2 \pm 0.22$ \\
\hline $\mathrm{Mg}\left(\mathrm{cmol}_{\mathrm{c}} \mathrm{kg}^{-1}\right)$ & $1.7 \pm 0.20$ & $1.7 \pm 0.17$ & $1.5 \pm 0.28$ & $0.6 \pm 0.19$ & $0.5 \pm 0.10$ & $0.4 \pm 0.08$ \\
\hline $\mathrm{K}\left(\mathrm{cmol}_{\mathrm{c}} \mathrm{kg}^{-1}\right)$ & $0.9 \pm 0.27$ & $0.7 \pm 0.12$ & $0.6 \pm 0.06$ & $0.5 \pm 0.13$ & $0.7 \pm 0.65$ & $0.4 \pm 0.09$ \\
\hline $\mathrm{Na}\left(\mathrm{cmol}_{\mathrm{c}} \mathrm{kg}^{-1}\right)$ & $1.6 \pm 0.32$ & $1.0 \pm 0.01$ & $1.4 \pm 0.35$ & $0.6 \pm 0.20$ & $0.5 \pm 0.22$ & $0.5 \pm 0.03$ \\
\hline $\mathrm{EA}\left(\mathrm{cmol}_{\mathrm{c}} \mathrm{kg}^{-1}\right)$ & $0.2 \pm 0.00$ & $0.2 \pm 0.10$ & $0.4 \pm 0.06$ & $0.8 \pm 0.51$ & $1.2 \pm 0.33$ & $1.3 \pm 0.30$ \\
\hline $\mathrm{CEC}\left(\mathrm{cmol}_{\mathrm{c}} \mathrm{kg}^{-1}\right)$ & $9.5 \pm 0.49$ & $8.1 \pm 0.28$ & $7.9 \pm 1.03$ & $4.9 \pm 0.70$ & $4.5 \pm 0.93$ & $3.7 \pm 0.32$ \\
\hline
\end{tabular}

${ }^{1}$ Walkley-Black; ${ }^{2}$ potenciometry; ${ }^{3}$ ammonium lactate; ${ }^{4}$ hot water, azomethine- $\mathrm{H} ;{ }^{5}$ ammonium acetate for bases and potassium chloride for exchangeable acidity (EA) from which effective cation-exchange capacity (CEC) was estimated 
At the end of July 2015 (30th), 2016 (22nd), and 2017 (24th), leaves were sampled to assess the nutritional status of the trees. A sample per tree was taken by collecting young mature leaves in all quadrants. At harvest, fruit samples were also taken for elemental analysis and evaluation of the amount of nutrients removed in the nuts.

\subsection{In Situ Measurements of Nutritional Status and Photosynthetic Performance of the Trees}

Estimates of greenness or relative chlorophyll content in plant leaves were recorded by using the portable SPAD-502 plus chlorophyll meter on the same days as the leaves were collected for elemental analysis. The device measures the transmittance of light through the leaf at two different wavelengths, $650 \mathrm{~nm}$ (red light, absorbed by chlorophyll pigments) and $940 \mathrm{~nm}$ (infrared light, not absorbed by chlorophyll). The readings were taken from the blade of fully expanded young leaves.

On the same dates, a NDVI (normalized difference vegetation index) was estimated by using the Field Scout CM $1000 \AA$ NDVI meter. The device senses the light at wavelengths of $660 \mathrm{~nm}$ and $840 \mathrm{~nm}$, measuring the ambient and reflected light at each of those wavelengths. The NDVI value (-1 to 1$)$ is calculated from the measured ambient and reflected light data [(\%Near Infrared - \%Red) / (\%Near Infrared + \%Red)].

Chlorophyll $a$ fluorescence measurements and advanced OJIP test were performed by using the OS-30p+ handheld portable fluorometer. The tool is designed to measure precisely chlorophyll $a$ fluorescence and transient fluorescence by using dark adaptation protocols $F_{\mathrm{V}} / F_{\mathrm{M}}, F_{\mathrm{V}} / F_{0}$ and advanced OJIP measurements. $F_{\mathrm{M}}$ and $F_{0}$ are the maximum and minimum fluorescence, respectively, and $F_{\mathrm{V}} / F_{\mathrm{M}}=\left(F_{\mathrm{M}}-F_{0}\right) / F_{\mathrm{M}}$ and $F_{\mathrm{V}} / F_{0}=\left(F_{\mathrm{M}}-F_{0}\right) / F_{0}$. The OJIP test provides origin (O) fluorescence at $20 \mu \mathrm{s}(\mathrm{O})$, fluorescence at $2 \mathrm{~ms}(\mathrm{~J})$, fluorescence at $30 \mathrm{~ms}(\mathrm{I})$, and maximum fluorescence or $F_{\mathrm{M}}(\mathrm{P})$. Measurements were taken from fully expanded young leaves, after a period of dark adaptation longer than $35 \mathrm{~min}$.

\subsection{Soil Testing and Plant Analysis}

Soil samples were dried $\left(40^{\circ} \mathrm{C}\right)$ to constant weight and sieved (2-mm mesh). The soil samples of the two field trials were submitted to analytical determinations: $\mathrm{pH}\left(\mathrm{H}_{2} \mathrm{O}, \mathrm{KCl}\right)$; easily oxidizable carbon $(\mathrm{C})$ determined by the Walkley-Black method; cation-exchange capacity (ammonium acetate, $\mathrm{pH}$ 7.0); extractable $\mathrm{P}$ and $\mathrm{K}$ (ammonium lactate); and extractable $\mathrm{B}$ (azomethine-H). In the initial samples, there were also determined clay, silt and sand fractions by the Robinson pipette method. All the determinations are fully described by Houba et al. (1997) and are the usual methods followed in the soil testing and plant analysis laboratories in Portugal.
Tissue samples (leaves and nuts) were oven-dried at $70^{\circ} \mathrm{C}$. Nuts were separated into kernel and shell before they were ground. Tissue analyses were performed by Kjeldahl (N), colorimetry (B and $\mathrm{P})$, flame emission spectrometry $(\mathrm{K})$, and atomic absorption spectrophotometry $(\mathrm{Ca}, \mathrm{Mg}, \mathrm{Cu}, \mathrm{Fe}, \mathrm{Zn}$, and $\mathrm{Mn}$ ) methods (Walinga et al. 1989) after tissue samples were fully digested for $40 \mathrm{~min}$ with nitric acid in a microwave.

\subsection{Data Analysis}

Data analysis was carried out using JMP software. Firstly, data was tested for normality and homogeneity of variances using the Shapiro-Wilk test and Bartlett's test, respectively. The comparison of the effect of the fertilizer treatments was provided by ANOVA. When significant differences $(\alpha<0.05)$ were found among the fertilizer treatments, the means were separated by the multiple range Tukey HSD test $(\alpha=0.05)$.

\section{Results}

\subsection{Soil Fertility Status}

Soil organic C content is roughly twice as high in Salgueiros in comparison to Sobreiró (Table 2) as previously recorded at the beginning of the experiments (Table 1). In both localities, soil organic $\mathrm{C}$ decreases with depth. Organic $\mathrm{C}$ contents in the $0-10$-cm layer are approximately twice the organic $\mathrm{C}$ contents in the 20-30-cm layer. Liming combined with NPK or only P did not influence the organic $\mathrm{C}$ content at any of the sites or at any depth.

In Sobreiró, fertilized treatments resulted in a significant increase in soil $\mathrm{pH}$ compared with the unfertilized control at all depths. Also, in Salgueiros, there was a pH increase in the fertilized treatments compared with the control, although significant differences were only recorded in the $0-10-\mathrm{cm}$ layer.

Extractable $\mathrm{P}$ increased in the fertilized treatments in comparison with the control. In Sobreiro the differences were significant at all depths while in Salgueiros the differences among treatments were more marked at the $0-10-\mathrm{cm}$ soil depth.

In Sobreiró, exchangeable Ca was significantly higher in the fertilized treatments at all depths compared with the control. In Salgueiros the trend was similar, although at the 20 $30-\mathrm{cm}$ soil layer the differences among treatments did not significantly differ. Overall, exchangeable $\mathrm{Ca}$ was higher in Sobreiró than in Salgueiros. Exchangeable Mg showed an opposite tendency to $\mathrm{Ca}$, with higher average values in the control treatments. However, at neither depth in either the Sobreiró or Salgueiros trials were the values in the control significantly higher than in the fertilized treatments. 
Table 2 Selected soil properties at the end of the experiments of Sobreiró and Salgueiros

\begin{tabular}{|c|c|c|c|c|c|c|}
\hline \multirow[b]{2}{*}{ Soil layer $(\mathrm{cm})$} & \multicolumn{3}{|l|}{ Sobreiró } & \multicolumn{3}{|c|}{ Salgueiros } \\
\hline & $0-10$ & $10-20$ & $20-30$ & $0-10$ & $10-20$ & $20-30$ \\
\hline \multicolumn{7}{|c|}{ Organic $\mathrm{C}\left(\mathrm{g} \mathrm{kg}^{-1}\right)$} \\
\hline Lime+NPK & $13.6 \mathrm{a}$ & $8.8 \mathrm{a}$ & $6.1 \mathrm{a}$ & $25.0 \mathrm{a}$ & $14.7 \mathrm{a}$ & $12.8 \mathrm{a}$ \\
\hline Lime+P & $12.4 \mathrm{a}$ & $8.6 \mathrm{a}$ & $5.9 \mathrm{a}$ & $28.5 \mathrm{a}$ & $14.4 \mathrm{a}$ & $13.6 \mathrm{a}$ \\
\hline Control & $12.5 \mathrm{a}$ & $9.1 \mathrm{a}$ & $6.5 \mathrm{a}$ & $27.1 \mathrm{a}$ & $16.2 \mathrm{a}$ & $13.7 \mathrm{a}$ \\
\hline \multicolumn{7}{|l|}{$\mathrm{pH}\left(\mathrm{H}_{2} \mathrm{O}\right)$} \\
\hline Lime+NPK & $5.9 \mathrm{a}$ & $5.7 \mathrm{a}$ & $5.3 \mathrm{a}$ & $5.4 \mathrm{a}$ & $4.7 \mathrm{a}$ & $4.6 \mathrm{a}$ \\
\hline Lime+P & $6.1 \mathrm{a}$ & $5.8 \mathrm{a}$ & $5.4 \mathrm{a}$ & $5.5 \mathrm{a}$ & $4.9 \mathrm{a}$ & $4.7 \mathrm{a}$ \\
\hline Control & $5.4 \mathrm{~b}$ & $5.2 \mathrm{~b}$ & $4.8 \mathrm{~b}$ & $5.0 \mathrm{~b}$ & $4.8 \mathrm{a}$ & $4.6 \mathrm{a}$ \\
\hline \multicolumn{7}{|c|}{ Extractable $\mathrm{P}\left(\mathrm{mg} \mathrm{P}_{2} \mathrm{O}_{5} \mathrm{~kg}^{-1}\right)$} \\
\hline Lime+NPK & $183.4 \mathrm{a}$ & $104.6 \mathrm{a}$ & $32.1 \mathrm{a}$ & $69.4 \mathrm{a}$ & $31.5 \mathrm{a}$ & $28.0 \mathrm{a}$ \\
\hline Lime+P & $169.5 \mathrm{a}$ & 88.9 a & $30.8 \mathrm{a}$ & $87.1 \mathrm{a}$ & $33.7 \mathrm{a}$ & $42.9 \mathrm{a}$ \\
\hline Control & $44.9 \mathrm{~b}$ & $29.6 \mathrm{~b}$ & $14.6 \mathrm{~b}$ & $22.5 \mathrm{~b}$ & $24.3 \mathrm{a}$ & $16.7 \mathrm{~b}$ \\
\hline \multicolumn{7}{|c|}{ Exchangeable $\mathrm{Ca}\left(\mathrm{cmol}+\mathrm{kg}^{-1}\right)$} \\
\hline Lime+NPK & $6.5 \mathrm{a}$ & $5.9 \mathrm{a}$ & $4.9 \mathrm{a}$ & $5.3 \mathrm{a}$ & $1.8 \mathrm{ab}$ & $1.3 \mathrm{a}$ \\
\hline Lime+P & $6.7 \mathrm{a}$ & $6.4 \mathrm{a}$ & $5.1 \mathrm{a}$ & $5.7 \mathrm{a}$ & $2.1 \mathrm{a}$ & $1.4 \mathrm{a}$ \\
\hline Control & $5.2 \mathrm{~b}$ & $4.9 \mathrm{~b}$ & $4.4 \mathrm{~b}$ & $3.2 \mathrm{~b}$ & $1.5 \mathrm{~b}$ & $1.2 \mathrm{a}$ \\
\hline \multicolumn{7}{|c|}{ Exchangeable $\mathrm{Mg}\left(\mathrm{cmol}+\mathrm{kg}^{-1}\right)$} \\
\hline Lime+NPK & $2.3 \mathrm{a}$ & $2.6 \mathrm{a}$ & $2.3 \mathrm{a}$ & $0.9 \mathrm{a}$ & $0.6 \mathrm{a}$ & $0.6 \mathrm{a}$ \\
\hline Lime+P & $2.6 \mathrm{a}$ & $2.7 \mathrm{a}$ & $2.4 \mathrm{a}$ & $0.8 \mathrm{a}$ & $0.7 \mathrm{a}$ & $0.6 \mathrm{a}$ \\
\hline Control & $2.7 \mathrm{a}$ & $3.2 \mathrm{a}$ & $2.2 \mathrm{a}$ & $1.0 \mathrm{a}$ & $0.7 \mathrm{a}$ & $0.7 \mathrm{a}$ \\
\hline
\end{tabular}

In columns, for each soil property, means followed by the same letter are not significantly different by Tukey's HSD test $(\alpha<0.05)$

Other soil fertility parameters, such as extractable K and B, did not show significant differences among treatments (data not shown).

\subsection{Plant Nutritional Status and Photosynthetic Performance}

The Lime+NPK treatment significantly increased the leaf N concentration in comparison with the other treatments, on two of the three sampling dates in either the Sobreiró or Salgueiros experiments (Fig. 2). The Lime+NPK and Lime+P fertilizer treatments did not increase leaf $\mathrm{P}$ concentration in any of the trials. Leaf $\mathrm{K}$ concentration tended to be higher in the Lime+ NPK treatment in comparison with the other treatments. However, significant differences were only recorded in one sample in the experiment of Salgueiros.

In Sobreiro the fertilized trees revealed significantly higher Ca levels than the trees of the control treatment in two of the three samplings (Table 3). Leaf $\mathrm{Mg}, \mathrm{B}, \mathrm{Fe}, \mathrm{Cu}$, and $\mathrm{Zn}$ concentrations did not significantly vary with fertilizer treatments and fell within the sufficiency ranges. Leaf Mn levels were significantly lower in the fertilized treatments compared with those of the control on all sampling dates, although the oscillations occurred within the sufficiency range.

In Salgueiros, a significant increase in leaf $\mathrm{Ca}$ levels was also recorded in the fertilized treatments in comparison with the control (Table 4). Mean leaf Ca concentrations were, however, lower than those reported from the experiment of Sobreiró. As in Sobreiró, leaf $\mathrm{Mg}, \mathrm{B}, \mathrm{Fe}, \mathrm{Cu}$, and $\mathrm{Zn}$ concentrations did not significantly vary with fertilizer applications. Unlike in Sobreiró, leaf Mn levels in Salgueiros did not significantly vary with treatments. The average leaf Mn levels in Salgueiros were, however, much higher than those in Sobreiró, although they did not reach $2000 \mathrm{mg} \mathrm{kg}^{-1}$, the upper limit of the sufficiency range.

No significant differences were found among treatments in nutrient concentrations in the nuts (kernel or shell) in any of the field trials. The mean results of all treatments in each of the trials are shown in Table 5. $\mathrm{N}$ was the most concentrated nutrient in the kernel, followed by K. Among micronutrients, Mn was the most concentrated in the kernel, in particular in the nuts of the experiment of Salgueiros, reaching $150 \mathrm{mg} \mathrm{kg}^{-1}$. In the shell, Ca was the most concentrated nutrient, although the shell maintained also appreciable levels of $\mathrm{N}$. Among the micronutrients, Mn was also the most concentrated in the shell in particular in the Salgueiros experiment, and the values were more than double than those in the kernel.

The measurements relating to the nutritional status and the photosynthetic performance of the trees revealed no significant differences between treatments in any of the years. The average values from the two experiments of the most relevant parameters are presented in Table 6. OJIP, $F_{\mathrm{V}} / F_{\mathrm{M}}, F_{\mathrm{V}} / F_{0}$, and NDVI values were lower in the 2015 measurement, which corresponds to the spring/summer period with the lowest rainfall. SPAD values were between 33.6 and 35.9, but did not follow any relevant trend. This does not mean that the perennial parts of the plant, especially the roots, not analyzed in this study, did not absorb highly useful $\mathrm{P}$ for later use.

\subsection{Nut Yield}

Yearly nut productions and cumulative totals did not vary significantly with fertilizer treatments in either trial (Fig. 3). However, in Salgueiros, the Lime+NPK treatment yielded a relatively higher cumulative average nut production, reaching $71.7 \mathrm{~kg}$ tree ${ }^{-1}$, while in the control, it was $59.6 \mathrm{~kg}$ tree $^{-1}$. In the Lime+P treatment, the average value was lower than that in the control treatment with $51.7 \mathrm{~kg}$ tree $^{-1}$.

\section{Discussion}

Lime applications supplemented with P or NPK did not significantly influence the organic matter content in the soil. While fertilization can stimulate the development of 
Fig. 2 Leaf N, P, and $\mathrm{K}$ concentrations from a Sobreiró and b Salgueiros trials as a function of fertilizer treatments. Horizontal full and dashed lines are, respectively, the lower (LLSR) and the higher (HLSR) limits of the sufficiency range. ANOVA results presented as * $(P<0.05), * *(P<0.01)$ and ns (not significant)
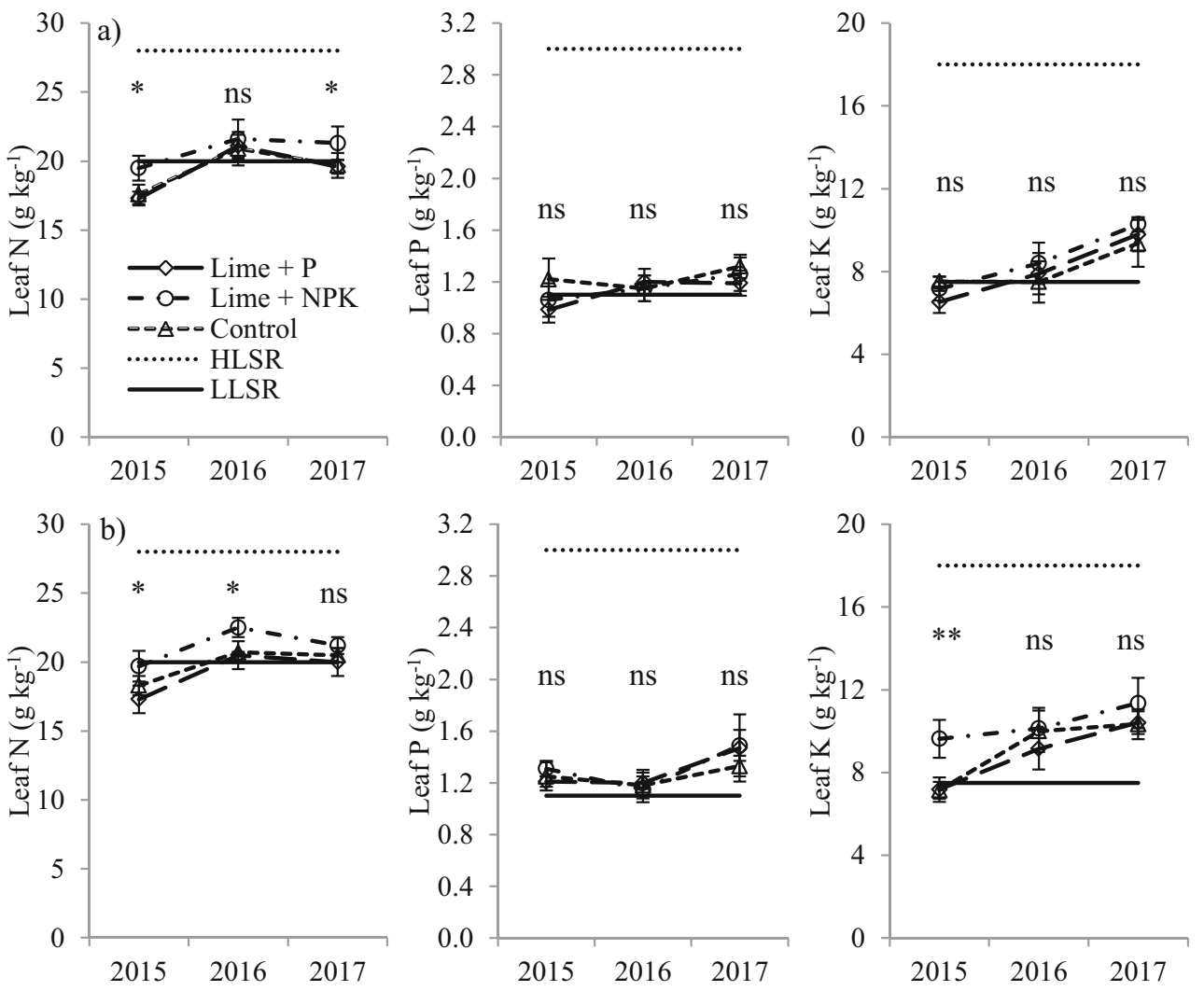

herbaceous vegetation, increasing the entry of organic substrate into the soil (Ferreira et al. 2015), the $\mathrm{pH}$ increase, in turn, may have stimulated microbial activity, which enhances organic substrate mineralization (Havlin et al. 2014; Santos 2015). The combined balance of these two effects may have resulted in the absence of significant differences between treatments in soil organic matter.

Lime applications raised the $\mathrm{pH}$ at all depths in the tilled soil (Sobreiró) and especially in the surface layer in the nontilled soil (Salgueiros). The application of lime will neutralize
Table 3 Nutrient concentrations in the leaves as a function of fertilizer treatments and years from the trial of Sobreiró

\begin{tabular}{|c|c|c|c|c|c|c|c|}
\hline & \multicolumn{7}{|c|}{ Sobreiró } \\
\hline & $\begin{array}{l}\mathrm{Ca} \\
\mathrm{g} \mathrm{kg}^{-1}\end{array}$ & $\mathrm{Mg}$ & $\begin{array}{l}\text { B } \\
\mathrm{mg} \mathrm{kg}^{-1}\end{array}$ & $\mathrm{Fe}$ & $\mathrm{Cu}$ & $\mathrm{Zn}$ & $\mathrm{Mn}$ \\
\hline \multicolumn{8}{|l|}{2015} \\
\hline Lime+NPK & $5.8 \mathrm{a}$ & $3.1 \mathrm{a}$ & $12.8 \mathrm{a}$ & $164.6 \mathrm{a}$ & $7.8 \mathrm{a}$ & $31.3 \mathrm{a}$ & $348.9 \mathrm{~b}$ \\
\hline Lime+P & $5.7 \mathrm{a}$ & $3.4 \mathrm{a}$ & $10.9 \mathrm{a}$ & $134.8 \mathrm{a}$ & $6.1 \mathrm{a}$ & $36.9 \mathrm{a}$ & $308.8 \mathrm{~b}$ \\
\hline Control & $5.6 \mathrm{a}$ & $3.4 \mathrm{a}$ & $14.8 \mathrm{a}$ & $165.3 \mathrm{a}$ & $6.3 \mathrm{a}$ & $28.6 \mathrm{a}$ & $455.0 \mathrm{a}$ \\
\hline \multicolumn{8}{|l|}{2016} \\
\hline Lime+NPK & $6.1 \mathrm{a}$ & $3.3 \mathrm{a}$ & $23.4 \mathrm{a}$ & $152.6 \mathrm{a}$ & $8.4 \mathrm{a}$ & $24.7 \mathrm{a}$ & $325.8 \mathrm{~b}$ \\
\hline Lime+P & $6.0 \mathrm{a}$ & $3.1 \mathrm{a}$ & $24.5 \mathrm{a}$ & $149.1 \mathrm{a}$ & $8.4 \mathrm{a}$ & $28.3 \mathrm{a}$ & $298.7 \mathrm{~b}$ \\
\hline Control & $5.2 \mathrm{~b}$ & $3.5 \mathrm{a}$ & $31.8 \mathrm{a}$ & $163.5 \mathrm{a}$ & $9.3 \mathrm{a}$ & $28.1 \mathrm{a}$ & $743.5 \mathrm{a}$ \\
\hline \multicolumn{8}{|l|}{2017} \\
\hline Lime+NPK & $6.2 \mathrm{a}$ & $3.2 \mathrm{a}$ & $15.7 \mathrm{a}$ & $142.5 \mathrm{a}$ & $9.1 \mathrm{a}$ & $24.5 \mathrm{a}$ & $324.3 \mathrm{~b}$ \\
\hline Lime+P & $6.0 \mathrm{a}$ & $2.6 \mathrm{a}$ & $16.8 \mathrm{a}$ & $146.8 \mathrm{a}$ & $8.2 \mathrm{a}$ & $29.3 \mathrm{a}$ & $272.8 \mathrm{~b}$ \\
\hline Control & $4.7 \mathrm{~b}$ & $2.6 \mathrm{a}$ & $19.2 \mathrm{a}$ & $145.9 \mathrm{a}$ & $7.9 \mathrm{a}$ & $30.9 \mathrm{a}$ & $919.8 \mathrm{a}$ \\
\hline Sufficiency range & $5-15$ & $1.5-6$ & $20-100$ & $15-300$ & $4-40$ & $15-75$ & $100-2000$ \\
\hline
\end{tabular}

In columns, within each year, means followed by the same letter are not significantly different by Tukey's HSD test $(\alpha<0.05)$ 
Table 4 Nutrient concentrations in the leaves as a function of fertilizer treatments and years from the trial of Salgueiros

\begin{tabular}{|c|c|c|c|c|c|c|c|}
\hline & \multicolumn{7}{|c|}{ Salgueiros } \\
\hline & $\begin{array}{l}\mathrm{Ca} \\
\mathrm{g} \mathrm{kg}^{-1}\end{array}$ & $\mathrm{Mg}$ & $\begin{array}{l}\text { B } \\
\mathrm{mg} \mathrm{kg}^{-1}\end{array}$ & $\mathrm{Fe}$ & $\mathrm{Cu}$ & $\mathrm{Zn}$ & Mn \\
\hline \multicolumn{8}{|l|}{2015} \\
\hline Lime+NPK & $4.3 \mathrm{a}$ & $1.6 \mathrm{a}$ & $12.2 \mathrm{a}$ & $132.6 \mathrm{a}$ & $7.2 \mathrm{a}$ & $34.2 \mathrm{a}$ & $1607.7 \mathrm{a}$ \\
\hline Lime+P & $3.6 \mathrm{ab}$ & $1.4 \mathrm{a}$ & $9.8 \mathrm{a}$ & $135.0 \mathrm{a}$ & $6.1 \mathrm{a}$ & $24.9 \mathrm{a}$ & $1913.3 \mathrm{a}$ \\
\hline Control & $3.0 \mathrm{~b}$ & $1.5 \mathrm{a}$ & $10.7 \mathrm{a}$ & $125.1 \mathrm{a}$ & $6.2 \mathrm{a}$ & $30.1 \mathrm{a}$ & $1812.7 \mathrm{a}$ \\
\hline \multicolumn{8}{|l|}{2016} \\
\hline Lime+NPK & $4.2 \mathrm{a}$ & $1.5 \mathrm{a}$ & $17.5 \mathrm{a}$ & $112.0 \mathrm{a}$ & $8.1 \mathrm{a}$ & $28.7 \mathrm{a}$ & $1438.1 \mathrm{a}$ \\
\hline Lime+P & $3.9 \mathrm{a}$ & $1.5 \mathrm{a}$ & $12.9 \mathrm{a}$ & $99.3 \mathrm{a}$ & $8.3 \mathrm{a}$ & $26.8 \mathrm{a}$ & $1612.1 \mathrm{a}$ \\
\hline Control & $3.3 \mathrm{~b}$ & $1.4 \mathrm{a}$ & $15.4 \mathrm{a}$ & $94.0 \mathrm{a}$ & $7.9 \mathrm{a}$ & $29.4 \mathrm{a}$ & $1514.2 \mathrm{a}$ \\
\hline \multicolumn{8}{|l|}{2017} \\
\hline Lime+NPK & $4.3 \mathrm{a}$ & $1.4 \mathrm{a}$ & $11.8 \mathrm{a}$ & $67.8 \mathrm{a}$ & $10.3 \mathrm{a}$ & $30.5 \mathrm{a}$ & $1357.7 \mathrm{a}$ \\
\hline Lime+P & $4.1 \mathrm{a}$ & $1.4 \mathrm{a}$ & $9.0 \mathrm{a}$ & $66.8 \mathrm{a}$ & $11.1 \mathrm{a}$ & $21.9 \mathrm{a}$ & $1153.3 \mathrm{a}$ \\
\hline Control & $2.1 \mathrm{~b}$ & $1.4 \mathrm{a}$ & $11.8 \mathrm{a}$ & $55.1 \mathrm{a}$ & $13.9 \mathrm{a}$ & $34.1 \mathrm{a}$ & $1484.2 \mathrm{a}$ \\
\hline Sufficiency range & $5-15$ & $1.5-6$ & $20-100$ & $15-300$ & $4-40$ & $15-75$ & $100-2000$ \\
\hline
\end{tabular}

In columns, within each year, means followed by the same letter are not significantly different by Tukey HSD test $(\alpha<0.05)$

$\mathrm{H}^{+}$, and the $\mathrm{Al}^{3+}$ in soil solution precipitates as $\mathrm{Al}(\mathrm{OH})_{3}$, and more exchangeable $\mathrm{Al}^{3+}$ will desorb to resupply solution $\mathrm{Al}^{3+}$. In the continuity of this reaction, more $\mathrm{Al}^{3+}$ will be neutralized and replaced on the exchangeable complex by the cations of the added base (Havlin et al. 2014). In this experiment, with the application of lime, exchangeable Ca increased but exchangeable $\mathrm{Mg}$ tended to decrease consistently even though without significant differences between treatments. The higher content of $\mathrm{Ca}$ in comparison with $\mathrm{Mg}$ in the lime might have produced a dilution effect of $\mathrm{Mg}$ in the soil solution and in the exchangeable complex. Extractable $\mathrm{P}$ also increased in the fertilized treatments likely due to the combined effect of $\mathrm{P}$ applications and $\mathrm{P}$ release by the increase of $\mathrm{pH}$. Liming acidic soils will precipitate $\mathrm{Fe}$ and $\mathrm{Al}$ as $\mathrm{Fe}(\mathrm{OH})_{3}$ and $\mathrm{Al}(\mathrm{OH})_{3}$, which usually increases soil P availability (Havlin et al. 2014), in spite of at short-term an opposite trend can be observed (Park and Ro 2018).

Lime and $\mathrm{P}$ applications increased the amount of extractable $\mathrm{P}$ in the soil, but the concentration of the element in the leaves did not increase. In tree species, the perennial woody parts act as a buffer for the concentration of nutrients in the leaves (Colin-Belgrand et al. 1996). Studies in potted olive trees, in which the $\mathrm{P}$ concentration in roots was evaluated, revealed that increased availability of $\mathrm{P}$ in the soil markedly increased $\mathrm{P}$ concentration in the roots and much less in the leaves (Ferreira et al. 2018a). In these large trees, the increase of available $\mathrm{P}$ in the soil was not enough to increase the concentration of the element in the leaves. $\mathrm{K}$ also did not increase in the leaves in the treatment that received a small amount of $\mathrm{K}$ (Lime+NPK). Studies on potted olive trees also showed a
Table 5 Average ( \pm standard deviation) nutrient concentrations in fruits (kernel and shell) from the trials of Sobreiró and Salgueiros

\begin{tabular}{|c|c|c|c|c|}
\hline & \multicolumn{2}{|l|}{ Kernel } & \multicolumn{2}{|l|}{ Shell } \\
\hline & Sobreiró & Salgueiros & Sobreiró & Salgueiros \\
\hline Nitrogen $\left(\mathrm{g} \mathrm{kg}^{-1}\right)$ & $9.40 \pm 1.08$ & $8.21 \pm 0.91$ & $2.55 \pm 0.45$ & $2.41 \pm 0.15$ \\
\hline Phosphorus $\left(\mathrm{g} \mathrm{kg}^{-1}\right.$ ) & $1.19 \pm 0.14$ & $1.13 \pm 0.14$ & $0.07 \pm 0.05$ & $0.05 \pm 0.03$ \\
\hline Potassium $\left(\mathrm{g} \mathrm{kg}^{-1}\right)$ & $6.48 \pm 0.45$ & $6.84 \pm 1.38$ & $1.07 \pm 0.51$ & $1.57 \pm 0.70$ \\
\hline Calcium $\left(\mathrm{g} \mathrm{kg}^{-1}\right)$ & $0.46 \pm 0.05$ & $0.53 \pm 0.08$ & $3.06 \pm 0.20$ & $2.12 \pm 0.23$ \\
\hline Magnesium $\left(\mathrm{g} \mathrm{kg}^{-1}\right)$ & $0.48 \pm 0.06$ & $0.50 \pm 0.07$ & $1.01 \pm 0.10$ & $1.04 \pm 0.15$ \\
\hline Boron $\left(\mathrm{mg} \mathrm{kg}^{-1}\right)$ & $8.41 \pm 1.71$ & $8.00 \pm 1.43$ & $13.82 \pm 2.75$ & $13.24 \pm 2.12$ \\
\hline Iron $\left(\mathrm{mg} \mathrm{kg}^{-1}\right)$ & $18.02 \pm 3.99$ & $12.69 \pm 2.43$ & $15.83 \pm 4.28$ & $31.87 \pm 4.10$ \\
\hline Manganese $\left(\mathrm{mg} \mathrm{kg}^{-1}\right)$ & $24.46 \pm 10.30$ & $150.00 \pm 46.44$ & $66.56 \pm 28.05$ & $365.35 \pm 98.94$ \\
\hline Copper (mg kg $\left.{ }^{-1}\right)$ & $9.30 \pm 1.41$ & $10.28 \pm 1.54$ & $4.46 \pm 0.71$ & $4.74 \pm 0.71$ \\
\hline Zinc (mg kg $\left.{ }^{-1}\right)$ & $19.80 \pm 2.64$ & $19.73 \pm 2.55$ & $34.84 \pm 3.61$ & $25.06 \pm 4.42$ \\
\hline
\end{tabular}


Table 6 Average ( \pm standard deviation) advanced OJIP measures, $F_{\mathrm{V}} /$ $F_{\mathrm{M}}, F_{\mathrm{V}} / F_{0}$, SPAD readings, and NDVI in fully expanded young leaves of the experiments of Sobreiró and Salgueiros

\begin{tabular}{llll}
\hline & $\begin{array}{l}\text { 2015 } \\
\text { July 30th }\end{array}$ & $\begin{array}{l}\text { Ju16 } 2 \text { nd } \\
\text { July }\end{array}$ & $\begin{array}{l}\text { 2017 } \\
\text { July 24th }\end{array}$ \\
\hline $\mathrm{O}$ & $253.2 \pm 35.5$ & $286.6 \pm 30.6$ & $259.4 \pm 39.9$ \\
J step & $406.1 \pm 57.7$ & $490.8 \pm 48.9$ & $426.8 \pm 65.4$ \\
I step & $714.8 \pm 89.1$ & $802.7 \pm 102.1$ & $732.8 \pm 87.8$ \\
P step & $925.9 \pm 64.8$ & $1009.0 \pm 93.8$ & $932.3 \pm 101.9$ \\
$F_{\mathrm{V}} / F_{\mathrm{M}}$ & $0.79 \pm 0.02$ & $0.82 \pm 0.02$ & $0.81 \pm 0.05$ \\
$F_{\mathrm{V}} / F_{0}$ & $4.06 \pm 0.38$ & $4.45 \pm 0.42$ & $4.28 \pm 0.87$ \\
$\mathrm{SPAD}$ & $35.8 \pm 1.4$ & $35.9 \pm 1.6$ & $33.6 \pm 2.1$ \\
$\mathrm{NDVI}$ & $0.80 \pm 0.01$ & $0.82 \pm 0.01$ & $0.83 \pm 0.02$ \\
\hline
\end{tabular}

$\mathrm{O}$ (origin), fluorescence value at $20 \mu \mathrm{s}$; J step, fluorescence value at $2 \mathrm{~ms}$; I step, fluorescence value at $30 \mathrm{~ms}$; P step (FM), maximum fluorescence; $F_{0}$, pre-photosynthetic minimum fluorescence; $F_{\mathrm{V}} / F_{\mathrm{M}}$, ratio of variable fluorescence to maximal fluorescence; $F_{\mathrm{V}} / F_{0}$, variable fluorescence normalized to minimum fluorescence; SPAD (soil and plant analysis development); NDVI (normalized difference vegetation index)

proportionally higher increase of $\mathrm{K}$ in roots than in leaves with increasing K availability in the soil (Ferreira et al. 2018b). N application, albeit at a small rate, had a significant effect on leaf $\mathrm{N}$ increase, with significant differences being noted on two sampling dates of each of the trials. Unlike P and K, previous studies showed that $\mathrm{N}$ increases proportionally more in the leaves than in the roots as soil $\mathrm{N}$ availability increases (Ferreira 2018).

The effect of lime and fertilizer applications on the concentration of other nutrients in the leaves was statistically significant only for $\mathrm{Ca}$ and $\mathrm{Mn}$. Liming increased soil $\mathrm{Ca}$ availability and consequently leaf $\mathrm{Ca}$ concentration. It should also be noted that leaf $\mathrm{Ca}$ levels were low if compared with the sufficiency range, and the trees of Salgueiros, grown on a more acidic soil and with less $\mathrm{Ca}$ in the exchangeable complex (Table 2), revealed levels of Ca below the lower limit of the sufficiency range. In previous studies, it has already been recorded that Ca may appear below the sufficiency range in some chestnut orchards of the region grown in acidic soils (Arrobas et al. 2018; Rodrigues et al. 2019). In Salgueiros, the applied lime did not raise leaf Ca levels to the sufficiency range, probably because the effectiveness of liming might have been reduced, due to not being incorporated into the soil. Leaf Mn concentrations decreased with the application of lime mainly in the trial of Sobreiró where the soil was tilled. The effect was not observed in Salgueiros. The concentration of $\mathrm{Mn}$ in soil solution mainly depends on soil $\mathrm{pH}$ (Marschner and Rengel 2012). Thus, the higher change in soil pH in the experiment of Sobreiró in comparison with Salgueiros may have favored the reduction of Mn bioavailability.

Fertilizer treatments had no significant effect on mineral content in the fruits. Their composition seems to be more stable than that of the leaves. $\mathrm{N}$ appears to be the most concentrated element in the fruits. Although nuts are considered to be low in protein and high in sugars (Echegaray et al. 2018), they are still a good source of total amino acids (Borges et al. 2008). Nuts are also rich in $K$, as other fruits, such as grapes (Arrobas et al. 2014), almonds (Arrobas et al. 2019) and olives (Rodrigues et al. 2012). Mn levels in nuts, particularly in the shell, were the highest among micronutrients due to the high presence of the element in the leaves. However, the levels of $\mathrm{Mn}$ in the nuts were incomparably lower than those in the leaves, indicating a strong restriction on $\mathrm{Mn}$ translocation from leaves to fruits, especially to pulp. The reduction of $\mathrm{Mn}^{2+}$ in fruit pulp was probably due to the compartmentalization of $\mathrm{Mn}^{2+}$ in the vacuoles and in the apoplast of leaves as shown for other species (Horst and Maier 1999). Ca and B are also elements that appeared in relatively high concentrations in shells due to the relevant role of these nutrients in the cell wall (Broadley et al. 2012; Hawkesford et al. 2012).

The reduced effect of the fertilized treatments on the general nutritional status of plants was similarly observed to the tests of chlorophyll fluorescence, NDVI and SPAD readings, since no significant differences between treatments were found to exist. However, in other studies, causal relationships between increased $\mathrm{P}$ nutrition and photosynthesis were often found (Veronica et al. 2017; Ferreira et al. 2018a). This may mean that in this particular study, the trees of the non-fertilized controls did not experience a clear situation of $\mathrm{P}$ deficiency. The effect of $\mathrm{P}$ or lime supply on the photochemical reactions
Fig. 3 Annual and accumulated nut yield as a function of fertilizer treatment. Letters above the columns are the results of ANOVA (no significant differences among treatments)
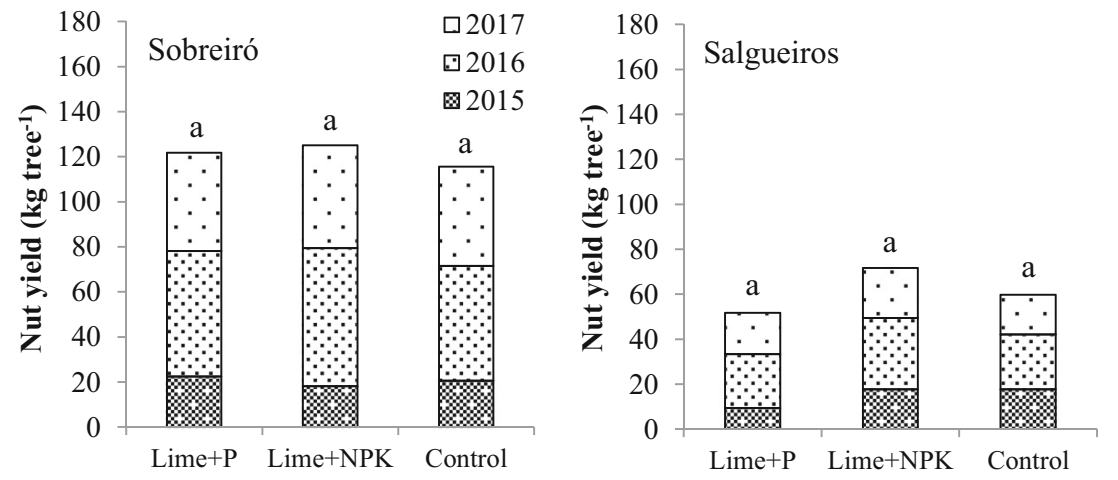
in the thylakoid membranes contributing to higher net $\mathrm{CO}_{2}$ assimilation rate will have been low. In contrast, it seems that $F_{\mathrm{V}} / F_{\mathrm{M}}, F_{\mathrm{V}} / F_{0}$, and all points of the OJIP curve values were lower in 2015 in comparison with the other years. The spring of 2015 was particularly dry, and these results probably reflect the increased drought stress to which the trees were exposed. Thus, water stress may have had a negative effect on the photochemical reactions of photosynthesis, in agreement with results obtained in other studies (Dinis et al. 2016; Ferreira et al. 2018b).

The effects of fertilizer treatments on plant nutritional status were not sufficient to significantly influence nut yield, since it depends on several other environmental variables besides nutrient availability. Productivity did not increase significantly but Lime+NPK treatments showed higher average values in particular in the experiment of Salgueiros. Given that $\mathrm{Ca}$ is at low levels in the leaves compared with the sufficiency range, it could be the main suspect influencing the slight increase observed in nut yield in the Lime+NPK treatments. However, the low nut yield in the Lime $+\mathrm{P}$ treatment rules out any role of the increased $\mathrm{Ca}$ availability in yield. Another possibility is N, since the Lime+NPK treatment was simultaneously associated with increased leaf $\mathrm{N}$ and higher yield and the leaf $\mathrm{N}$ concentration was also close to the lower limit of the sufficiency range. In this study, leaf B levels often appeared below the lower limit of the sufficiency range (Arrobas et al. 2018). Previous studies in the region also reported $\mathrm{B}$ as one of the elements which can cause nutritional disorders in chestnut trees (Portela et al. 2011, 2015; Rodrigues et al. 2019).

\section{Conclusions}

Despite the initial acidity of the soils and the effect of liming on the increase of soil $\mathrm{pH}$ and exchangeable calcium $(\mathrm{Ca})$ in the treated plots, the photosynthetic performance of the trees, assessed by $F_{\mathrm{V}}$ (variable fluorescence) $/ F_{\mathrm{M}}$ (maximum fluorescence), $F_{\mathrm{V}} / F_{0}$ (minimum fluorescence) and OJIP (origin fluorescence at $20 \mu \mathrm{s}$, fluorescence at $2 \mathrm{~ms}$, fluorescence at $30 \mathrm{~ms}$, and maximum fluorescence) test, and the crop productivity did not significantly change. These results indicate that the chestnut tree probably is a species well adapted to acidic soils, which can satisfactory grown with low levels of $\mathrm{Ca}$ in the leaves. Thus, in chestnut tree, liming should be viewed with caution and is probably only warranted on very acidic soils.

Phosphorus $(\mathrm{P})$ addition was not effective in leaf $\mathrm{P}$ increase or tree yield performance. This does not mean that the perennial parts of the plant, especially the roots, not analyzed in this study, have not absorbed valuable $\mathrm{P}$ for later use. One important clue from this work is that annual application of P may not be necessary, since the perennial structure can buffer the levels of $\mathrm{P}$ in the leaves. Another clue from these trials is the need for regular application of nitrogen $(\mathrm{N})$ to keep the levels of the nutrient in the leaves within the sufficiency range. Thus, it seems that the buffer that the perennial structure of such large trees offers, on the distribution of nutrients in the plant, is smaller for $\mathrm{N}$ than for $\mathrm{P}$. In addition, $\mathrm{N}$ is removed at relatively high levels in fruits and this nutrient does not accumulate in soils in balanced ecosystems, which accentuates the need for regular $\mathrm{N}$ applications, even in a large tree such as chestnut.

Acknowledgments The authors are grateful to the Foundation for Science and Technology (FCT, Portugal) and FEDER under Programme PT2020 for financial support to CIMO (UID/AGR/00690/ 2015) and FEADER (The European Agricultural Fund for Rural Development) through the project CMP122 - PDR2020-101-030981 EGIS, Estratégias para uma Gestão Integrada do Solo e da Água em Espécies Produtoras de Frutos Secos. We also thank João Paulo Roxo and Carlos Lopes for allowing the experiments to be conducted on their farms.

\section{Compliance with Ethical Standards}

Conflict of Interest The authors declare that they have no conflict of interest.

\section{References}

Abreu CG (2007) A origem e dispersão do castanheiro pelo mundo. In: Gomes-Laranjo J, Ferreira-Cardoso J, Portela E, Abreu CG (eds) Universidade de Trás-os-Montes e Alto Douro, Vila Real, Portugal, pp 15-21

Arrobas M, Ferreira IQ, Freitas S, Verdial J, Rodrigues MA (2014) Guidelines for fertilizer use in vineyards based on nutrient content of grapevine parts. Sci Hortic 172:191-198

Arrobas M, Sandra A, Ferreira I, Rodrigues MA (2016) Estudos de fertilização do castanheiro: resultados preliminares. Revista Voz do Campo (jan/fev 2015): Agrociência VIII-IX

Arrobas M, Afonso S, Ferreira IQ, Moutinho-Pereira JM, Correia CM, Rodrigues MA (2017) Liming and application of nitrogen, phosphorus, potassium and boron on a young plantation of chestnut. Turk $\mathrm{J}$ Agric For 41:441-451

Arrobas M, Afonso S, Rodrigues MA (2018) Diagnosing the nutritional condition of chestnut groves by soil and leaf analyses. Sci Hortic 228:113-121

Arrobas M, Ribeiro AC, Barreales D, Pereira E, Rodrigues MA (2019) Soil and foliar nitrogen and boron fertilization of almond trees grown under rainfed conditions. Eur J Agron 106:39-48

Borges O, Gonçalves B, Soeiro JL (2008) Nutritional quality of chestnut (Castanea sativa mill.) cultivars from Portugal. Food Chem 106: 976-984

Broadley M, Brown P, Cakmak I, Rengel Z, Zhao F (2012) Function of nutrients: micronutrients. In: Marschner P (ed) Marschner's mineral nutrition of higher plants. Elsevier, London, pp 191-248

Colin-Belgrand M, Ranger J, Bouchon J (1996) Internal nutrient translocation in chestnut tree stemwood: III. Dynamics across an age series of Castanea sativa (Miller). Ann Bot 78:729-740

Dinis L-T, Ferreira H, Pinto G, Bernardo S, Correia CM, MoutinhoPereira J (2016) Kaolin-based, foliar reflective film protects photosystem II structure and function in grapevine leaves exposed to heat and high solar radiation. Photosynthetica 54:47-55 
Echegaray N, Gomez B, Barba FJ, Franco D, Estevez M, Carballo J, Marszałek K, Lorenzo JM (2018) Chestnuts and by-products as source of natural antioxidants in meat and meat products: a review. Trends Food Sci Technol 82:110-121

Ferreira IQ (2018) Estudos de fertilização de azoto, fósforo, potássio e boro em oliveira. $\mathrm{PhD}$ thesis, Universidad de Léon, Spain

Ferreira IQ, Rodrigues MA, Claro AM, Arrobas M (2015) Management of nitrogen-rich legume cover crops as a mulching in traditional olive orchards. Commun Soil Sci Plant Anal 46:1881-1894

Ferreira IQ, Rodrigues MA, Moutinho-Pereira JM, Correia C, Arrobas M (2018a) Olive tree response to applied phosphorus in field and pot experiments. Sci Hortic 234:236-244

Ferreira IQ, Arrobas M, Moutinho-Pereira JM, Correia C, Rodrigues MA (2018b) Olive response to potassium applications under different water regimes and cultivars. Nutr Cycl Agroecosyst 112:387-401

Gençer NS, Mert C (2019) Studies on the gall characteristics of Dryocosmus kuriphilus in chestnut genotypes in Yalova and Bursa provinces of Turkey. Not Bot Hort Agrobo 47(1):177-182

Gomes-Laranjo J, Coutinho JP, Peixoto F, Alves JA (2007) Ecologia do castanheiro (C. sativa Mill.). In: Gomes-Laranjo J, Ferreira-Cardoso J, Portela E, Abreu CG (eds) Universidade de Trás-os-Montes e Alto Douro, Vila Real, Portugal, pp 109-114

Gouveia ME, Choupina A, Coelho V, Monte E, Hermosa R, Abreu CG (2005) Diagnosis of ink disease of chestnut by molecular identification of associated Phytophthora species. Acta Hortic 639:585-589

Havlin JL, Tisdale SL, Nelson WL, Beaton JD (2014) Soil fertility and fertilizers, an introduction to nutrient management, 8th edn. Pearson, Boston

Hawkesford M, Horst W, Kichey T, Lambers H, Schjoerring J, Moller IS, White P (2012) Functions of macronutrients. In: Marschner P (ed) Marschner's mineral nutrition of higher plants. Elsevier, London, pp 135-189

Horst WJ, Maier P (1999) Compartmentation of manganese in the vacuoles and in the apoplast of leaves in relation to genotypic manganese leaf-tissue tolerance in Vigna unguiculata (L.) Walp. In: GisselNielsen G, Jensen A (eds) Plant nutrition - molecular biology and genetics. Kluwer Academic Publisher, pp 223-234

Houba VJG, van der Lee JJ, Novozamsky I (1997) Soil analysis procedures. Other Procedures. Landbouwuniversiteit Wagningen

Krebs P, Pezzatti GB, Beffa G, Tinner W, Conedera M (2019) Revising the sweet chestnut (Castanea sativa Mill.) refugia history of the last glacial period with extended pollen and macrofossil evidence. Quat Sci Rev 206:111-128

Marschner P, Rengel Z (2012) Nutrient availability in soils. In: Marschner $P$ (ed) Marschner's mineral nutrition of higher plants. Elsevier, London, pp 315-330

Maurel M, Robin C, Capron G, Desprez-Loustau M-L (2001) Effects of root damage associated with Phytophthora cinnamomi on water relations, biomass accumulation, mineral nutrition and vulnerability to water deficit of Æve oak and chestnut species. For Pathol 31:353369

Murolo S, Concas J, Romanazzi G (2019) Use of biocontrol agents as potential tools in the management of chestnut blight. Biol Control 132:102-109
Nunes L, Coutinho J, Nunes LF, Castro Rego F, Lopes D (2011) Growth, soil properties and foliage chemical analysis comparison between pure and mixed stands of Castanea sativa Mill. and Pseudotsuga menziesii (Mirb.) Franco, in Northern Portugal. Forest Syst 20(3): 496-507

Park J-S, Ro H-M (2018) Early-stage changes in chemical phosphorus speciation induced by liming deforested soils. J Soil Sci Plant Nutr $18: 435-447$

Pereira MG, Caramelo L, Gouveia C, Gomes-Laranjo J, Magalhães M (2011) Assessment of weather-related risk on chestnut productivity. Nat Hazards Earth Syst Sci 11:2729-2739

Pereira E, Coelho V, Tavares RM, Lino-Neto T, Baptista P (2012) Effect of competitive interactions between ectomycorrhizal and saprotrophic fungi on Castanea sativa performance. Mycorrhiza 22:41-49

Portela E, Ferreira-Cardoso JV, Louzada JL (2011) Boron application on a chestnut orchard: effect on yield and quality of nuts. J Plant Nutr 34:1245-1253

Portela E, Ferreira-Cardoso J, Louzada J, Gomes-Laranjo J (2015) Assessment of boron application in chestnuts: nut yield and quality. J Plant Nutr 38:973-987

Righetti TL, Wilder KL, Cummings GA (1990) Plant analysis as an aid in fertilizing orchards. In: Westermann RL (ed) Soil testing and plant analysis, 3rd edn. Book Series no. 3. SSSA, Madison, pp 563-601

Rodrigues MA, Ferreira IQ, Claro AM, Arrobas M (2012) Fertiliser recommendations for olive based upon nutrients removed in crop and pruning. Sci Hortic 142:205-211

Rodrigues MA, Grade V, Barroso V, Pereira A, Cassol LC, Arrobas M (2019) Chestnut response to organo-mineral and controlled-release fertilizers in rainfed growing conditions. J Soil Sci Plant Nutr 19(4). https://doi.org/10.1007/s42729-019-00119-7

Rusu ME, Simedrea R, Gheldiu A-M, Mocan A, Vlase L, Popa D-S, Ferreira ICFR (2019) Benefits of tree nut consumption on aging and age-related diseases: mechanisms of actions. Trends Food Sci Technol 88:104-120

Santos JQ (2015) Fertilização: fundamentos agroambientais da utilização dos adubos e corretivos. Publindústria, Porto

Veronica N, Subrahmanyam D, Vishnu Kiran T, Yugandhar P, Bhadana VP, Padma V, Jayasree G, Voleti SR (2017) Influence of low phosphorus concentration on leaf photosynthetic characteristics and antioxidant response of rice genotypes. Photosynthetica 55:285-293

Walinga I, van Vark W, Houba V, van der Lee J (1989) Soil and plant analysis: part 7 - plant analysis procedures. Wageningen Agricultural University, Wageningen

WRB (2015) World Reference Base for Soil Resources 2014, Update 2015. International Soil Classification Systems for Naming Soils and Creating Legends for Soil Maps. World Soil Resources Reports No. 106. FAO, Rome

Publisher's note Springer Nature remains neutral with regard to jurisdictional claims in published maps and institutional affiliations. 